\title{
TITLE: MONITORING OCULAR HYPERTENSION, HOW MUCH AND HOW OFTEN? A
} COST-EFFECTIVENESS PERSPECTIVE

\begin{abstract}
Sub title: For confirmed ocular hypertension, primary treatment and subsequent monitoring of treatment responsiveness is more efficient than biennial testing to detect glaucoma. Further data is needed to define the optimal glaucoma risk threshold for initiating treatment.
\end{abstract}

Hernández $\mathrm{R}^{1}$; Burr, $\mathrm{JM}^{2}$; Vale, $\mathrm{L}^{3}$ Azuara- Blanco, $\mathrm{A}^{4}$; Cook, JA ${ }^{5}$; Banister, $\mathrm{K}^{6}$; Tuulonen, $\mathrm{A},{ }^{7}$ Mandy Ryan ${ }^{1}$; for the Surveillance of Ocular Hypertension Study group ${ }^{*}$

*(membership of group listed at end of paper)

1. Research Fellow, Health Economics Research Unit, Institute of Applied Health Sciences, University of Aberdeen, Polwarth Building, Foresterhill, Aberdeen, AB25 2ZD, UK

2. Reader in Medicine, School of Medicine, University of St Andrews, St Andrews, Fife KY16 9TF, UK

3. Health Foundation Chair in Health Economics, Health Economics Group, Institute of Health \& Society, Newcastle University, Baddiley-Clark Building, Richardson Road, Newcastle upon Tyne, NE2 4AA, UK

4. Professor of Ophthalmology, School of Medicine, Dentistry and Biomedical Sciences, Queen's University Belfast, BT12 6BA

5. Associate Professor, Centre for Statistics in Medicine, Nuffield Department of Orthopaedics, Rheumatology and Musculoskeletal Sciences, University of Oxford, Botnar Research Centre, Nuffield Orthopaedic Centre, Windmill Road, Oxford, OX3 7LD.

6. Research Fellow, Health Services Research Unit, Institute of Applied Health Sciences, University of Aberdeen, Health Sciences Building, Foresterhill, Aberdeen, AB25 2ZD, UK

7. Professor, Director of Tays Eye Centre, Tampere University Hospital, FIN-33521, Tampere, Finland

8. Professor, Health Economics Research Unit, Institute of Applied Health Sciences, University of Aberdeen, Polwarth Building, Foresterhill, Aberdeen, AB25 2ZD, UK

Corresponding author: Jennifer Burr jmb28@st-andrews.ac.uk

Key words: ocular hypertension, glaucoma; monitoring; discrete event simulation; cost-effectiveness 
ABSTRACT

Objective: To assess the efficiency of alternative monitoring services for people with ocular hypertension (OHT), a glaucoma risk factor.

Design: Discrete event simulation model comparing five alternative care pathways: treatment at OHT diagnosis with minimal monitoring; biennial monitoring (primary and secondary care) with treatment if baseline predicted 5-year glaucoma risk is $\geq 6 \%$; monitoring and treatment aligned to National Institute for Health and Care Excellence (NICE) glaucoma guidance (conservative and intensive).

Setting: UK health services perspective

Participants: Simulated cohort of 10,000 adults with ocular hypertension (Mean Intraocular Pressure (IOP) $24.9 \mathrm{mmHg}(\mathrm{SD} 2.4)$.

Main outcome measures: Costs, glaucoma detected, quality adjusted life years (QALYs).

Results: Treating at diagnosis was the least costly and least effective in avoiding glaucoma and progression. Intensive monitoring following NICE guidance was most costly and effective. However, considering a wider cost-utility perspective, biennial monitoring was less costly and provided more QALYS than NICE pathways, but was unlikely to be cost-effective compared with treating at diagnosis (£86,717 per additional QALY gained). The findings were robust to risk thresholds for initiating monitoring but were sensitive to treatment threshold, NHS service costs and treatment adherence.

Conclusions: For confirmed ocular hypertension, glaucoma monitoring more frequently than every two years is unlikely to be efficient. Primary treatment and minimal monitoring (assessing treatment responsiveness [IOP]) could be considered, however further data to refine glaucoma risk prediction models and value patient preferences for treatment are needed. Consideration to innovative and affordable service redesign focused on treatment responsiveness rather than more glaucoma testing is recommended.

(WORD COUNT 249) 


\section{INTRODUCTION}

Avoiding sight loss is a public health priority [1] but decisions have to be made in terms of how best to manage eye care across competing demands. In the UK, about 24,000 people are newly registered with sight loss each year (blind and partial sight) with glaucoma being second to macular degeneration as the leading cause.[2,3] Although ocular hypertension is the main and only modifiable risk factor for glaucoma [4,5] organising a monitoring programme to monitor intraocular pressure (IOP) and detect early glaucoma has the potential to overburden health care and patients. Choices have to be made.

The UK National Institute for Health and Care Excellence (NICE) clinical guideline for glaucoma[6] recommends long-term monitoring of ocular hypertension in specialist (health care professional accredited in glaucoma) led service either in secondary care (consultant led hospital eye service) or primary care (community optometry) depending on local commissioning arrangements. Thresholds for initiating ocular hypotensive treatment are defined proportionate to glaucoma risk with stratification based upon the findings of a Markov economic model.[6] Recommended monitoring intervals were informed by a budget impact analysis and expert opinion. However, concerns were subsequently raised that glaucoma services are overburdened with monitoring low risk disease.[7]

This study compares plausible alternative monitoring programmes for ocular hypertension (varying monitoring intervals, setting and treatment thresholds) to inform eye care policy in the UK. The study is part of a wider programme of work commissioned by the National Institute of Health Research, Health Technology Assessment programme to determine the optimum surveillance for people with ocular hypertension and is reported elsewhere in full. [8]

\section{METHODS}

We developed a discrete event simulation model[8] to assess the relative efficiency of monitoring a simulated cohort of 10,000 people with confirmed ocular hypertension (defined as an IOP $>21 \mathrm{mmHg}$ and no clinical signs of glaucoma) in the UK. We estimated cost-effectiveness (cost per glaucoma cases detected) and cost-utility (cost per incremental quality adjusted life year [QALY] gained) over 20 years, adopting a NHS perspective and discounted costs and benefits at the recommended 3.5\% discount rate. [9] All costs are reported in 2009-2010 Pound Sterling. The model structure is described in full elsewhere.[8] 
In brief, we compared five care pathways: three 'new' care pathways and two based upon the existing NICE recommended pathways for ocular hypertension, i.e. guidance for current care, see table 1. The three 'new' care pathways were (i) monitoring people with ocular hypertension biennially in secondary (consultant led eye care) or (ii) biennially in primary eye care (glaucoma trained community clinician [optometrist or General Practitioner] led care). In both 'biennial' pathways, ocular hypotensive treatment was modelled when the baseline risk of glaucoma was $\geq 6 \%$ based on a glaucoma five-year risk estimator. [10] For those requiring treatment, responsiveness was assessed at 2 months and a $<15 \%$ reduction in IOP prompted treatment escalation by adding a topical betablocker. As an extreme alternative, we also modelled a pathway where for confirmed ocular hypertension (iii) treatment was initiated irrespective of glaucoma risk stratification with annual IOP monitoring by community optometrist. A $<15 \%$ reduction in IOP prompted referral into secondary care with monitoring according to NICE OHT pathway.[6] The NICE monitoring guidance was summarised as (iv) an intensive pathway representing a monitoring interval between 4-12 months and (v) a more conservative pathway with monitoring intervals between 6-24 months. These two NICE informed pathways reflect variations in the recommended monitoring frequency in the NICE guideline.[6] The monitoring interval in both NICE pathways depended on baseline risk stratification based on age, IOP and central corneal thickness (CCT), factors regarded as predictors of glaucoma (see appendix table A1 for a detailed description of the NICE informed pathways included in our model). In all five pathways, if conversion to glaucoma occurred, subsequent care was in the hospital eye service according to the NICE glaucoma treatment guideline.[6]

Table 1 Modelled care pathways for monitoring confirmed ocular hypertension

\begin{tabular}{|c|c|c|c|}
\hline Pathway & $\begin{array}{l}\text { Baseline risk stratification } \\
\text { for treatment }\end{array}$ & Treatment allocation & $\begin{array}{l}\text { Monitoring interval and } \\
\text { type of monitoring }\end{array}$ \\
\hline $\begin{array}{l}\text { (i) Biennial review - } \\
\text { Primary care } \\
\text { (Glaucoma } \\
\text { accredited } \\
\text { optometrist or } \\
\text { General } \\
\text { Practitioner) }\end{array}$ & $\begin{array}{l}\text { 5-year glaucoma risk estimator } \\
{[10]}\end{array}$ & $\begin{array}{l}\text { PGA initiated if } 5 \text { year } \\
\text { glaucoma risk } \geq 6 \% * \mathrm{BB} \\
\text { added if }<15 \% \text { reduction in } \\
\text { IOP }\end{array}$ & $\begin{array}{l}\text { Two yearly glaucoma } \\
\text { assessment } \uparrow[8] \\
\text { If IOP off target or } \\
\text { conversion to glaucoma } \\
\text { detected refer to secondary } \\
\text { care }\end{array}$ \\
\hline $\begin{array}{l}\text { (ii) Biennial review } \\
\text { - Secondary care } \\
\text { (Consultant led) }\end{array}$ & $\begin{array}{l}\text { 5-year glaucoma risk estimator } \\
{[10]}\end{array}$ & $\begin{array}{l}\text { PGA initiated if } 5 \text { year } \\
\text { glaucoma risk } \geq 6 \% \text {. } * \text { BB } \\
\text { added if }<15 \% \text { reduction in } \\
\text { IOP }\end{array}$ & $\begin{array}{l}\text { Two yearly glaucoma } \\
\text { assessment } \dagger[8]\end{array}$ \\
\hline (iii)'Treat all' & $\begin{array}{l}\mathrm{IOP}>21 \mathrm{mmHg} \\
\text { No further risk stratification }\end{array}$ & PGA if $\mathrm{IOP}>21 \mathrm{mmHg}$ & $\begin{array}{l}\text { IOP monitoring once a } \\
\text { year in primary care } \\
\text { optometry and no } \\
\text { glaucoma assessment. If } \\
\text { IOP }<15 \% \text { reduction from } \\
\text { baseline refer to hospital } \\
\text { eye care according to NICE } \\
\text { OHT guideline. [6] }\end{array}$ \\
\hline (iv) NICE & NICE guideline (based on age, & NICE guideline with & NICE guideline. Using \\
\hline
\end{tabular}


informed- NICE

CCT and IOP, see Appendix

modifications $* *[6]$

$\underline{\text { minimum intervals }}$

intensive table A1) [6]

between monitoring

visits[6]

(v) NICE informed

- NICE

NICE guideline (based on age, CCT and IOP) [6]

NICE guideline with modifications $* *$ [6]

NICE guideline. Using

conservative maximum intervals between monitoring visits[6]

IOP, Intraocular Pressure; PGA, prostaglandin analogue; CCT, Central Corneal Thickness

* All those starting treatment, or requiring a treatment change have two consecutive (same day) IOP within two months of starting or changing treatment $\dagger I O P$, perimetry and optic nerve assessment $* * P e o p l e$ with $C C T<555$ $\mu \mathrm{m}$ and on a PGA are treated until either 65years if $21 \mathrm{mmHg}<1 O P \leq 25 \mathrm{mmHg}$ or $80 \quad$ years if $25 \mathrm{mmHg}<I O P<32 \mathrm{mmHg}$. Untreated low risk individuals, (CCT $>590 \mu \mathrm{m}$ and IOP $<32 \mathrm{mmHg})$ with stable IOP, are not discharged in our model and this is a deviation from the NICE guideline.

Apart from the 'treat all' pathway, each simulated individual within the model had a predefined glaucoma risk, which was based on the natural history of open angle glaucoma estimated from the distribution of predictors in a European derived population.[11] The mean age of the simulated population cohort was 57 years, with lower and upper inter quartile range limits of 51 and 64 respectively, and mean IOP of $25 \mathrm{mmHg}$ ranging from 21-36mmHg. The underlying distribution of IOP in the simulated cohort over time was estimated from predictions of a mixed linear regression model based on IOP data from an untreated ocular hypertension cohort and described in detail elsewhere.[8] The uncertainty due to measurement variability according to tonometer used was also included. [12]

We populated the model with data from systematic reviews and statistical modelling estimates of the variability in IOP measurements and visual field indices[8] based on data from the placebo arms of two randomised controlled ocular hypertension treatment trials.[11,13] Details are described in table 2 . 
Table 2 Model data (natural history, efficacy and diagnostic accuracy/agreement)

\begin{tabular}{|c|c|c|c|}
\hline Description & Mean (years) & $\begin{array}{l}\text { Probability } \\
\text { distribution* (mean, } \\
\text { variance) }\end{array}$ & Source \\
\hline \multicolumn{4}{|l|}{ Glaucoma progression $\dagger$} \\
\hline $\begin{array}{l}\text { Time of progression from early } \\
\text { glaucoma to moderate glaucoma }\end{array}$ & 4 & $\operatorname{Normal}(4,2)$ & $\begin{array}{l}\text { Untreated. Variance based on } \\
\text { assumption.[14] }\end{array}$ \\
\hline $\begin{array}{l}\text { Time of progression from moderate } \\
\text { to severe glaucoma }\end{array}$ & 9 & Normal $(9,2)$ & $\begin{array}{l}\text { Untreated. Variance based on } \\
\text { assumption.[14] }\end{array}$ \\
\hline $\begin{array}{l}\text { Time of progression from severe } \\
\text { glaucoma to visual impairment }\end{array}$ & 10 & $\operatorname{Normal}(10,2)$ & $\begin{array}{l}\text { Untreated. Variance based on } \\
\text { assumption.[14] }\end{array}$ \\
\hline \multicolumn{4}{|l|}{ Treatment efficacy } \\
\hline & $\begin{array}{c}\text { Mean IOP reduction } \\
(\%)\end{array}$ & \multicolumn{2}{|l|}{ Source } \\
\hline BB vs. no Treatment & 12 & \multicolumn{2}{|c|}{$\begin{array}{l}\text { Developed based on weighted mean differences in NICE } \\
\text { guideline[6] }\end{array}$} \\
\hline PGA vs. BB & 5 & \multicolumn{2}{|c|}{$\begin{array}{l}\text { Developed based on weighted mean differences in NICE } \\
\text { guideline[6] }\end{array}$} \\
\hline PGA + BB vs. PGA & 1.5 & \multicolumn{2}{|c|}{$\begin{array}{l}\text { Developed based on weighted mean differences in NICE } \\
\text { guideline[6] }\end{array}$} \\
\hline \multicolumn{4}{|c|}{ Treatment effectiveness (risk of glaucoma or progressive glaucoma) } \\
\hline \multicolumn{4}{|c|}{ Reduction in risk of progression from any medical treatment (hazard ratio) } \\
\hline Ocular hypertension & 0.56 & \multicolumn{2}{|l|}{ Maier et al 2007[15] } \\
\hline Glaucoma & 0.65 & \multicolumn{2}{|l|}{ Maier et al 2005[15] } \\
\hline \multicolumn{4}{|l|}{ Glaucoma surgery } \\
\hline $\begin{array}{l}\text { Proportion (of those converting to } \\
\text { glaucoma) requiring } \\
\text { trabeculectomy over } 20 \text { years }\end{array}$ & $8.50 \%$ & \multicolumn{2}{|l|}{ Burr et al 2012 [16] } \\
\hline $\begin{array}{l}\text { Proportion with successful } \\
\text { trabeculectomy (success defined as } \\
\text { no need for additional laser or } \\
\text { surgery) }\end{array}$ & $\begin{array}{l}88 \% \text { at } 1 \text { year and } 79 \% \text { at } \\
\text { year } 4\end{array}$ & \multicolumn{2}{|l|}{ Burr et al 2012 [16] } \\
\hline
\end{tabular}

\section{Measurement precision and accuracy of glaucoma detection} Ophthalmologist

\begin{tabular}{|c|c|c|}
\hline IOP measurement error $(\mathrm{mmHg}) \dagger$ & 1 & $\begin{array}{l}\text { Based on regression model in Burr 2012. [8] } \\
\text { Sampled from a normal distribution (mean, 0; } \\
\text { variance, } 0.036 \text { ) }\end{array}$ \\
\hline Sensitivity & 1 & Assumption \\
\hline Specificity & 1 & Assumption \\
\hline \multicolumn{3}{|c|}{ Primary care (optometrist or glaucoma specialist GP) } \\
\hline IOP measurement error $(\mathrm{mmHg}) \S$ & 0 & $\begin{array}{l}\text { Cook, 2012[12] Sampled from a normal } \\
\text { distribution (mean 0; variance 5.76) }\end{array}$ \\
\hline Sensitivity & 0.76 & Azuara-Blanco 2007 [17] \\
\hline Specificity & 0.93 & Azuara-Blanco 2007 [17] \\
\hline \multicolumn{3}{|c|}{$\begin{array}{l}\text { * Probability distributions are used to simulate a hypothetical cohort of people with ocular hypertension; details are } \\
\text { described in the text below. } \\
\dagger \text { Monocular visual field loss, mean deviation (MD in decibels }(\mathrm{dB}) \text { ) Mild glaucoma, } 0.01 \text { to }-6.00 \mathrm{~dB} \text {; moderate glaucoma, }- \\
6.01 \text { to }-12.0 \mathrm{~dB} \text {; severe glaucoma, }-12.01 \text { to }-20.00 \mathrm{~dB} \text {; visual impairment }-20.01 \mathrm{~dB} \text { to worse. [18] } \\
\text { + error term used in the model to reflect variability in IOP based on cohort data [8] } \\
\S \text { error term used in the model to reflect inter observer error in tonometry [8][12] }\end{array}$} \\
\hline
\end{tabular}


Data on the adherence to treatment (eye drops) were sparse and varied widely. We assumed, based on expert opinion (three ophthalmologists) treatment adherence was $75 \%$ except for the 'treat all' monitoring pathways where we assumed lower adherence, $50 \%$. Non-adherence was modelled as if untreated. Cost and utility data, see table 3, were derived from the British National Formulary (BNF) and data from 255 people with glaucoma[18] valued using UK population tariffs. We assumed that the score for those with ocular hypertension was the same as for mild glaucoma.

Table 3: Costs and utility estimates

\begin{tabular}{|c|c|c|}
\hline Description & 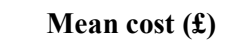 & Source \\
\hline \multicolumn{3}{|l|}{ Cost of monitoring } \\
\hline \multicolumn{3}{|l|}{ Secondary care attendance } \\
\hline IOP measurement only & 90 & $\begin{array}{l}\text { Information Services Division, NHS Scotland (Table R044X } \\
\text { Specialty group costs for consultant -Ophthalmology- } \\
\text { outpatients) }\end{array}$ \\
\hline Full glaucoma assessment & 180 & $\begin{array}{l}\text { Information Services Division, NHS Scotland (Table R044X } \\
\text { Specialty group costs for consultant -Ophthalmology- } \\
\text { outpatients) }\end{array}$ \\
\hline \multicolumn{3}{|l|}{ Primary care attendance } \\
\hline IOP measurement only & 10.35 & Assumption \\
\hline Full glaucoma assessment & 20.7 & $\begin{array}{l}\text { Department of Health. General Ophthalmic Services: NHS } \\
\text { sight test fee }\end{array}$ \\
\hline \multicolumn{3}{|l|}{ Cost of treatment } \\
\hline $\begin{array}{l}\text { Beta blockers ( } £ \text { per year of } \\
\text { treatment) }\end{array}$ & 18.72 & $\begin{array}{l}\text { BNF based on Timolol non-proprietary, } 0.5 \%, 5 \mathrm{ml}=£ 1.56 \text {. } \\
\text { Assumed } 1 \text { bottle per month }\end{array}$ \\
\hline $\begin{array}{l}\text { Prostaglandin analogues ( } £ \text { per } \\
\text { year of treatment) }\end{array}$ & 149.76 & $\begin{array}{l}\text { BNF based on Xalatan }{ }^{\circledR}, 2.5 \mathrm{ml}=£ 12.48 \text {. Assumed } 1 \text { bottle } \\
\text { per month }\end{array}$ \\
\hline $\begin{array}{l}\text { PGA }+ \text { beta blockers ( } £ \text { per } \\
\text { year of treatment })\end{array}$ & 171.84 & $\begin{array}{l}\text { BNF based on Xalacom }{ }^{\circledR}, 2.5 \mathrm{ml}=£ 14.32 \text {. Assumed } 1 \text { bottle } \\
\text { per month }\end{array}$ \\
\hline Glaucoma surgery & 1479 & NHS Reference Costs 2008-09 (HRG BZ18Z) \\
\hline \multicolumn{3}{|c|}{ European Quality of Life-5 Dimensions (EQ5D) utility weights } \\
\hline Health state* & Mean score & Source/note \\
\hline OHT & 0.8015 & Assumed equal to early glaucoma \\
\hline Mild glaucoma & 0.8015 & Burr 2007[18] \\
\hline Moderate glaucoma & 0.7471 & Burr 2007[18] \\
\hline Severe glaucoma & 0.7133 & Burr 2007[18] \\
\hline $\begin{array}{l}\text { OAG visually impaired } \\
\text { Visual impairment }\end{array}$ & 0.535 & Burr 2007[18] \\
\hline
\end{tabular}

We addressed uncertainty by running one-way sensitivity analyses on a simulated cohort of 1000 individuals. Sensitivity analyses included changing the following parameters in the biennial pathways: 
(i) increasing the glaucoma risk threshold for initiating surveillance (e.g. from 6-50\% as opposed to surveillance for all with confirmed ocular hypertension as in the base case); (ii) increasing the glaucoma risk threshold for initiating treatment (from $\geq 6 \%$ in the base case to a $50 \% 5$-year predicted risk of glaucoma) to explore the effects of treating only a high risk group and (iii) changes to the unit price of treatment with a prostaglandin analogue (a. pricing at $50 \%$ of the value in table 3 and $b$. pricing prostaglandin analogue at beta blocker prices - table 3); (iv) varying the price of monitoring visits (exploring the upper and lower limits of the interquartile range in the NHS reference costs) and (v) varying adherence from $50-20 \%$ for the 'Treat all' pathway and $75-95 \%$ for the more active monitoring pathways.

\section{RESULTS}

The baseline characteristics of the simulated individual characteristics are described in Table 4 .

Table 4 Simulated individual characteristics at start of the model, $n=10,000$

\begin{tabular}{|c|c|c|c|c|c|}
\hline Variable & $\begin{array}{c}\text { Age } \\
\text { (years) }\end{array}$ & Initial IOP (mmHg) & CCT $(\mu \mathrm{m})$ & PSD (dB) & VCD ratio \\
\hline $\begin{array}{l}\text { Mean } \\
(\mathrm{SD})\end{array}$ & $57(9.8)$ & $24.9(2.4)$ & $574.5(31.7)$ & $1.8(0.3)$ & $0.4(0.2)$ \\
\hline $\begin{array}{l}\text { Median } \\
(\mathrm{IQR})\end{array}$ & $57.1(13.2)$ & $24.6(3.3)$ & $574.2(42.3)$ & $1.8(0.4)$ & $0.4(0.2)$ \\
\hline
\end{tabular}

Over a 20-year time horizon the risk of converting to early glaucoma using the five monitoring strategies varied between 21-23\%. The 'treat all' pathway (ocular hypotensive drops initiated irrespective of glaucoma risk, annual IOP monitoring in primary care with referral to secondary care if IOP treatment response was inadequate) was the least costly and least effective in terms of number of people progressing to glaucoma, table 4. NICE intensive monitoring was the most effective in avoiding conversion to and progression of glaucoma but the most costly pathway. Taking a broader perspective, by including quality of life, the differences in QALYS between any of the monitoring pathways are small as only a modest number of people in the cohort progress to any stage of glaucoma. Biennial monitoring in secondary care is more costly but provides more QALYS than a 'treat all' pathway. However the incremental cost-effectiveness ratio (ICER), in moving from the 'treat all' pathway to biennial monitoring in secondary care, of around $£ 87,000$ is much larger than the usual maximum threshold of willingness to pay (WTP) for a QALY adopted by NICE in considering implementation of new policies (£20-30,000 per QALY gained). [9]

Table 5 Clinical effectiveness and cost-utility analysis

Clinical effectiveness of alternative monitoring pathways. $\quad \mathrm{N}=10,000$ 


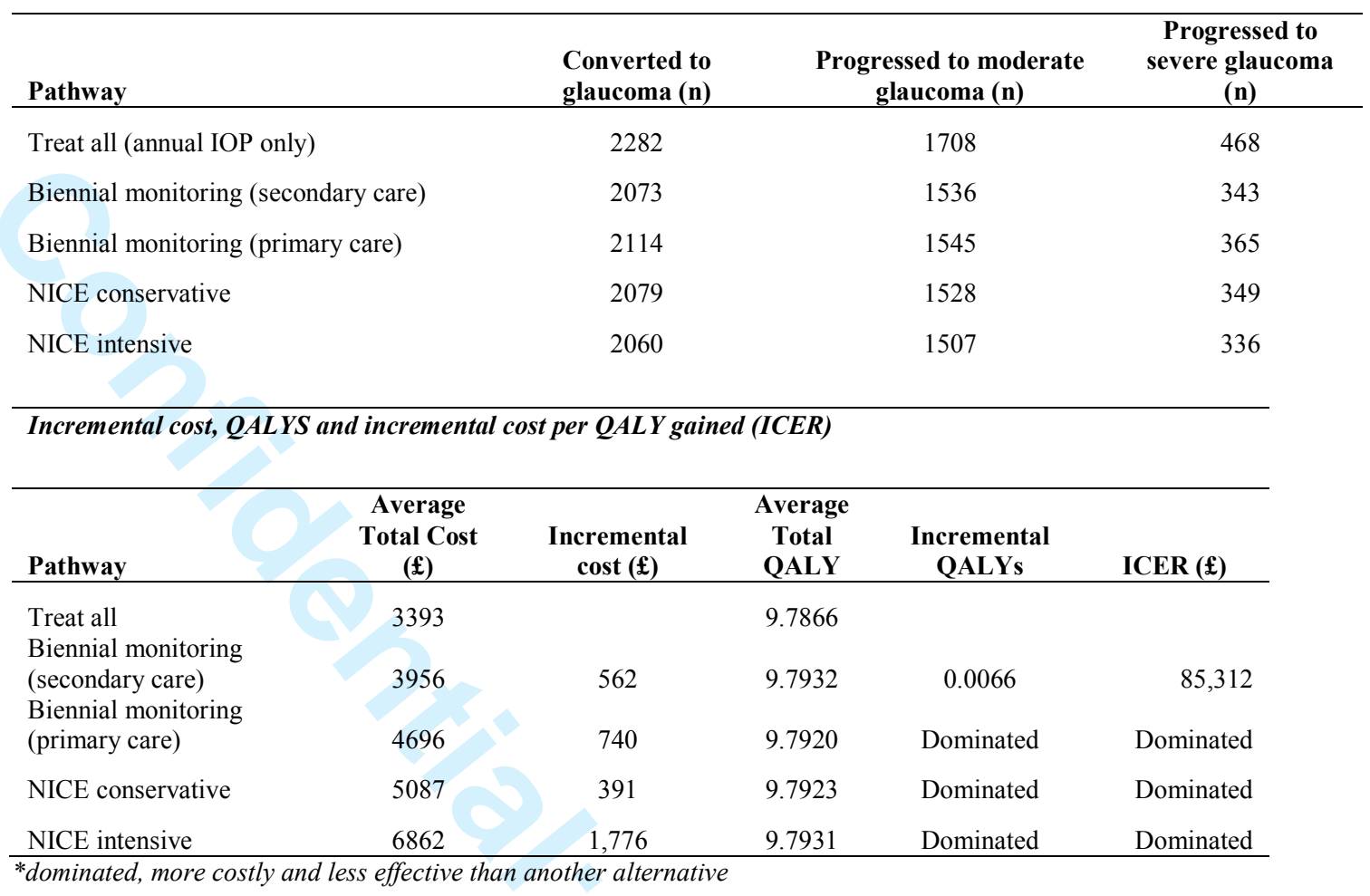

A summary of the findings of the sensitivity analyses is presented as on line supplementary material (Appendix 2). The results were not sensitive to varying the risk threshold for initiating surveillance (6-50\%) but were sensitive to increasing the threshold for treatment. When the treatment threshold was increased to a 5 -year glaucoma risk of $15 \%$ the biennial monitoring pathway (secondary care) dominated the 'treat-all' pathway (less costly and resulted in more QALYs). Sensitivity analyses around unit costs of treatment did not change the ICERs substantially. Varying the unit price of treatment with a prostaglandin analogue reduced the average costs for all pathways particularly those that involved more treatment ('treat all') but as expected no effect was observed on QALYS as only the unit costs of treatment changed.

The findings of the base case analysis were sensitive to varying unit costs for health care visits for a glaucoma-monitoring visit (including perimetry) and visits to measure IOP in response to treatment. If the unit cost of hospital visit was reduced from the base case value (£180) to £73 and an IOP only visit from $£ 90$ to $£ 51$, biennial monitoring in secondary care was cost effective compared with a 'treat-all' pathway, ICER $£ 10,857$ per QALY gained. Retaining the hospital glaucoma assessment at base case level (£180) but reducing the costs of an IOP visit, if the unit cost of an eye care visit was $£ 50-55$, biennial monitoring in secondary care was cost effective, ICER $£ 11,410$ per QALY gained.

The results were also sensitive to varying the estimated adherence to ocular hypotensive treatment. When adherence decreased for a 'treat-all 'pathway the cost effectiveness of biennial monitoring 
improved, e.g. assuming a 30\% adherence in the 'treat all' pathway and $75 \%$ adherence in a biennial pathway the ICER is $£ 26,334$.

\section{DISCUSSION}

We modelled less intensive pathways than recommended in the current NICE glaucoma guideline[6] to explore optimal treatment thresholds and monitoring intervals for people with ocular hypertension. Additionally, we used findings from statistical models of cohort data to inform an individual's risk stratification and the frequency of monitoring in our biennial monitoring pathways. These data were not available when the NICE clinical guideline was developed. Although effective at reducing the incidence of glaucoma, based on this study's findings, pathways based on current NICE recommended pathways are unlikely to be cost-effective from a UK policy perspective compared with the alternative approaches we explored. Initiating treatment as soon as ocular hypertension is identified with minimal monitoring once the target IOP is reached is the least costly approach and compared with the alternative pathways modelled could be seen as the most cost-effective (balancing cost and QALYs gained). Alternatively, based on the sensitivity analyses, initiating treatment if the 5 -year glaucoma risk was $>10 \%$, minimising the cost of repeat eye care visits and supporting patient adherence to treatment, with subsequent glaucoma tests every two years could be an efficient approach for surveillance of ocular hypertension. There are uncertainties regarding the optimal glaucoma risk threshold for initiating treatment, service costs, and long-term adherence to medication. The impact of any treatment side effects may not be fully captured in QALY estimates.

These findings should be interpreted bearing in mind the limitations of the data available to populate the model. In particular, natural history data represented ocular hypertensive populations included in randomised controlled trials and are not necessarily generalisable to those with ocular hypertension presenting to routine eye care services.

We used a discrete event simulation model, which simulates the costs and consequences of individual patients, enabling disease modelling and event complexities that are difficult to model in simpler more commonly used modelling approaches such as decision tree or Markov models. In any modelling exercise there are uncertainties in model structure, i.e. are the care pathways modelled appropriate, parameter uncertainty regarding the data used and time horizon of the model? We used recommended best practice methods to ensure validity of the model. This included extensive validation and calibration exercises. As part of the model implementation process we verified, validated (to verify the model fits the empirical data) and calibrated the model where needed. We simulated individual characteristics for a population of 1000 people at the point where they enter into the model. The data were interpreted alongside data from the literature to judge face validity. [11]. In addition, we ran the 
model for shorter time horizons and confirmed that glaucoma conversion was consistent with the literature.[10,19]

We developed the care pathways using the NICE glaucoma guideline as a representation of current recommended practice for managing ocular hypertension. This may not reflect actual practice around the UK but was a standardised comparator. We developed two pathways capturing the extremes of the NICE recommended pathways, based on these extremes the cost-effectiveness of anything in between could be inferred. As there is limited capacity in hospital eye care services, we developed alternative pathways to test whether less intensive monitoring would be a cost-effective option for a national health service. These alternative monitoring scenarios were developed in consultation with ophthalmologists, nurses, patients and the public[8] and a recent economic evaluation in the Netherlands that suggested that a treating ocular hypertension irrespective of glaucoma risk was a cost-effective approach in a Dutch context. [20] As neither of the extreme scenarios based on NICE were cost-effective compared with minimal glaucoma monitoring it is unlikely that any other strategy consistent with NICE guidance would be cost-effective. However it should be noted that the original version of the model did not allow for people deemed at low risk of developing glaucoma (CCT $>590$ micrometres and IOP $<32 \mathrm{mmHg}$ ) to be discharged after having a stable IOP for more than 3 years. We added this condition in a subsequent model development and the base case results reported in Table 5 remain robust. Discharged individuals move to yearly check-ups at a community optometrist and while the NICE informed strategies become, on average, less costly, they are not costeffective compared with the other modelled strategies.

We used data from systematic reviews of glaucoma risk prediction tools and statistical models determining the optimum frequency of monitoring IOP to detect true change from measurement noise to populate the model. For the statistical model we used serial measures of IOP and explored visual field data from the placebo group of randomised controlled treatment trials $[11,13]$ which may not be representative of variability in the general population. Repeat measures of visual fields were sparse in these trial data thus the model estimates were based solely on IOP data. It should be noted, however, that in the trial cohorts the visual fields (mean deviation) showed no true change over four years.[8]

We characterised the risk of developing glaucoma using a glaucoma 5-year risk estimator[21] and applied this risk prediction model to the simulated cohort. This glaucoma risk model has good predictive utility for estimating the 5-year risk of open angle glaucoma in an external validation study.[19] It is available as an online tool and may be easier to use in clinical practice than risk stratification based on age, CCT and IOP as in the NICE guideline although this has not been evaluated as far as we are aware. In two of our 'new' pathways, ocular hypotensive treatment was 
initiated if the predicted 5 -year risk of glaucoma was $\geq 6 \%$. This cut-off was based on the Ocular Hypertension Treatment Study cohort where low glaucoma five-year risk was defined arbitrarily as $<6 \%$, moderate as $6-13 \%$ and high-risk as $>13 \%$. [22]

We took a 20-year time horizon, which might not be sufficiently long to fully capture the impact on vision in a condition (i.e. glaucoma) that is slowly progressive for most people. We chose this horizon as extrapolating 5-year effectiveness data to even longer time horizons would be questionable. If we had taken a lifetime horizon more cases of visual impairment would have occurred, but given the time it takes to develop visual impairment, discounting would have reduced their impact on any differences between alternative pathways.

A similar evaluation was conducted in the Netherlands, investigating direct treatment initiation in ocular hypertension evaluated from a societal perspective with a lifetime horizon.[20] Direct pressure lowering treatment was less costly and more effective than a strategy of delaying treatment until early signs of glaucoma are apparent. The uncertainty surrounding the model parameters did not affect the conclusions. In the Dutch model adherence to treatment was not taken into account as it was assumed that it was an implicit part of the treatment effectiveness estimates. However, these estimates were from selected trial populations where adherence may be greater than in clinical practice.. We explored varying adherence based on published estimates, [23-25] further data would reduce the uncertainty in our findings.

Findings were also sensitive to the costs of repeat visits to assess treatment responsiveness (IOP) but were not sensitive to medication costs. For community monitoring we used a cost of $£ 20.70$ based upon the NHS sight test tariff. Should this cost be too low, for example should additional charges be incurred for the use of additional tests, then a higher cost would make community monitoring even less cost-effective than the base case results indicate.

In summary, we find no clear benefit in terms of cost-effectiveness from intensive monitoring of people with ocular hypertension to detect glaucoma. Innovative restructuring of the ophthalmic service, which is less costly and has greater emphasis on treatment responsiveness rather than more glaucoma testing is recommended. The feasibility of alternative and more affordable monitoring pathways should be explored. A rigorously designed prospective comparative study comparing low intensity surveillance (incorporating alternative treatment thresholds) with current practice is recommended.

Data sharing: All authors agree to allow review of the data by British Journal of Ophthalmology upon request from the corresponding author. 
Contributors: JMB, AAB, LV, MR, and JC contributed to the conception and design of the study. JMB, RH, LV, JC, AAB, KB and AT contributed to data acquisition. RH develop and conducted the economic model under supervision by LV. JMB drafted the article. All authors contributed to the interpretation of the results, revised the article critically for important intellectual content and gave final approval for publication.

Competing interests: There are no conflicts of interest.

Acknowledgements: Members of the Surveillance for Ocular Hypertension Study Group: Jennifer Burr, Adriana Botello-Pinzon, Yemisi Takwoingi, Rodolfo Hernández, Maria Vazquez-Montes, Andrew Elders, Ryo Asaoka, Katie Banister, Josine van der Schoot, Cynthia Fraser, Anthony King, Hans Lemij, Roshini Sanders, Stephen Vernon, Anja Tuulonen, Aachal Kotecha, Paul Glasziou, David Garway-Heath, David Crabb, Luke Vale, AugustoAzuara-Blanco, Rafael Perera, Mandy Ryan, Jonathan Deeks and Jonathan Cook.

Funding: This work was part of the Surveillance for Ocular Hypertension study funded by the National Institute for Health Research (NIHR) Health Technology Assessment Programme (07/46/02) The funding organisation had no role in the design or conduct of this research.

\section{References}

1 England NHS. Improving eye health and reducing sight loss - a call to action. 2014;:132.http://www.england.nhs.uk/wp-content/uploads/2014/06/eye-cta-pack.pdf

2 Bunce C, Xing W, Wormald R. Causes of blind and partial sight certifications in England and Wales: April 2007-March 2008. Eye (London, England) 2010;24:1692-9. doi:10.1038/eye.2010.122

3 Scottish Government SAH, Regent Road, Edinburgh EH1 3DG Tel:0131 5568400 ceu@scotland.gsi.gov.uk. Registered Blind and Partially Sighted Persons, Scotland 2010 . 2010.

4 Hollands H, Johnson D, Hollands S, et al. Do findings on routine examination identify patients at risk for primary open-angle glaucoma? The rational clinical examination systematic review. Jama 2013;309:2035-42. doi:10.1001/jama.2013.5099 [doi]

$5 \quad$ Vass C, Hirn C, Sycha T, et al. Medical interventions for primary open angle glaucoma and ocular hypertension. Cochrane Database of Systematic Reviews 2007;:3167. 
6 CG85 Glaucoma: diagnosis and management of chronic open angle glaucoma and ocular hypertension document on the Internet]. National Institute for Health and Clinical Excellence. 2009.http://guidance.nice.org.uk/CG85/Guidance/pdf/English

7 Ackland D, Kumaran N, Zia R. Treating glaucoma: the not-so-nice guidance. The British journal of ophthalmology 2014;98:1139-40. doi:10.1136/bjophthalmol-2013-304621 [doi]

Burr JM, Botello-Pinzon P, Takwoingi Y, et al. Surveillance for ocular hypertension: an evidence synthesis and economic evaluation. Health technology assessment (Winchester, England) 2012;16:1-271. doi:10.3310/hta16290

9 Guide to the methods of technology appraisal document on the Internet]. National Institute for Health and Clinical Excellence.

2008.http://www.nice.org.uk/media/B52/A7/TAMethodsGuideUpdatedJune2008.pdf

10 Ocular Hypertension Treatment Study Group and the European Glaucoma Prevention SG. The accuracy and clinical application of predictive models for primary open-angle glaucoma in ocular hypertensive individuals. Ophthalmology 2008;115:2030-6.

11 Reus NJ, Colen TP, Lemij HG. The prevalence of glaucomatous defects with short-wavelength automated perimetry in patients with elevated intraocular pressures. Journal of glaucoma. 2005;14:26-9.

12 Cook JA, Botello AP, Elders A, et al. Systematic Review of the Agreement of Tonometers with Goldmann Applanation Tonometry. Ophthalmology Published Online First: 10 May 2012. doi: 10.1016/j.ophtha.2012.02.030

13 Kamal D, Garway-Heath D, Ruben S, et al. Results of the betaxolol versus placebo treatment trial in ocular hypertension. Graefe's Archive for Clinical and Experimental Ophthalmology. 2003;241:196-203.

14 Burr J, Hernández R, Ramsay C, et al. Is it worthwhile to conduct a randomized controlled trial of glaucoma screening in the United Kingdom? Journal of health services research \& policy 2014;19:42-51. doi:10.1177/1355819613499748

15 Maier P, Funk J, Schwarzer G, et al. Treatment of ocular hypertension and open angle glaucoma: meta-analysis of randomised controlled trials. BMJ 2005;331:134. doi:10.1136/bmj.38506.594977.E0

16 Burr J, Azuara-Blanco A, Avenell A, et al. Medical versus surgical interventions for open angle glaucoma. Cochrane database of systematic reviews (Online) 2012;9:CD004399. doi:10.1002/14651858.CD004399.pub3; 10.1002/14651858.CD004399.pub3

17 Azuara-Blanco A, Burr J, Thomas R, et al. The accuracy of accredited glaucoma optometrists in the diagnosis and treatment recommendation for glaucoma. British Journal of Ophthalmology 2007;91:1639-43.

18 Burr JM, Kilonzo M, Vale L, et al. Developing a preference-based Glaucoma Utility Index using a discrete choice experiment. Optometry and Vision Science 2007;84:797-808.

19 Takwoingi Y, Botello AP, Burr JM, et al. External validation of the OHTS-EGPS model for predicting the 5-year risk of open-angle glaucoma in ocular hypertensives. The British journal of ophthalmology 2014;98:309-14. doi:10.1136/bjophthalmol-2013-303622 
20 van Gestel A, Schouten JS, Beckers HJ, et al. The long term effectiveness and costeffectiveness of initiating treatment for ocular hypertension. Acta Ophthalmologica Published Online First: 16 December 2013. doi:10.1111/aos.12328 [doi]

21 Glaucoma5-Year Risk Estimator based on results of the ocular hypertension treatment study and the European Glaucoma Prevention Study. http://ohts.wustl.edu/risk/ (accessed 28 Nov2014).

22 Kass MA, Gordon MO, Gao F, et al. Delaying treatment of ocular hypertension: the ocular hypertension treatment study. Archives of Ophthalmology 2010;128:276-87. doi:10.1001/archophthalmol.2010.20; 10.1001/archophthalmol.2010.20

23 Waterman H, Evans JR, Gray TA, et al. Interventions for improving adherence to ocular hypotensive therapy. The Cochrane database of systematic reviews 2013;4:CD006132. doi:10.1002/14651858.CD006132.pub3

24 Olthoff CM, Hoevenaars JG, van den Borne BW, et al. Prevalence and determinants of nonadherence to topical hypotensive treatment in Dutch glaucoma patients. Graefe's archive for clinical and experimental ophthalmology = Albrecht von Graefes Archiv fur klinische und experimentelle Ophthalmologie 2009;247:235-43. doi:10.1007/s00417-008-0944-y

25 Healey P, Goldberg I, Subramaniam K, et al. Persistence and adherence to glaucoma treatment in Australia. World Glaucoma Association. 2011. 


\section{Appendix 1}

Table AI Treatment and monitoring pathways developed from the NICE guideline. [6]

Treatment allocation criteria (NICE informed pathways: NICE intensive and NICE conservative)*

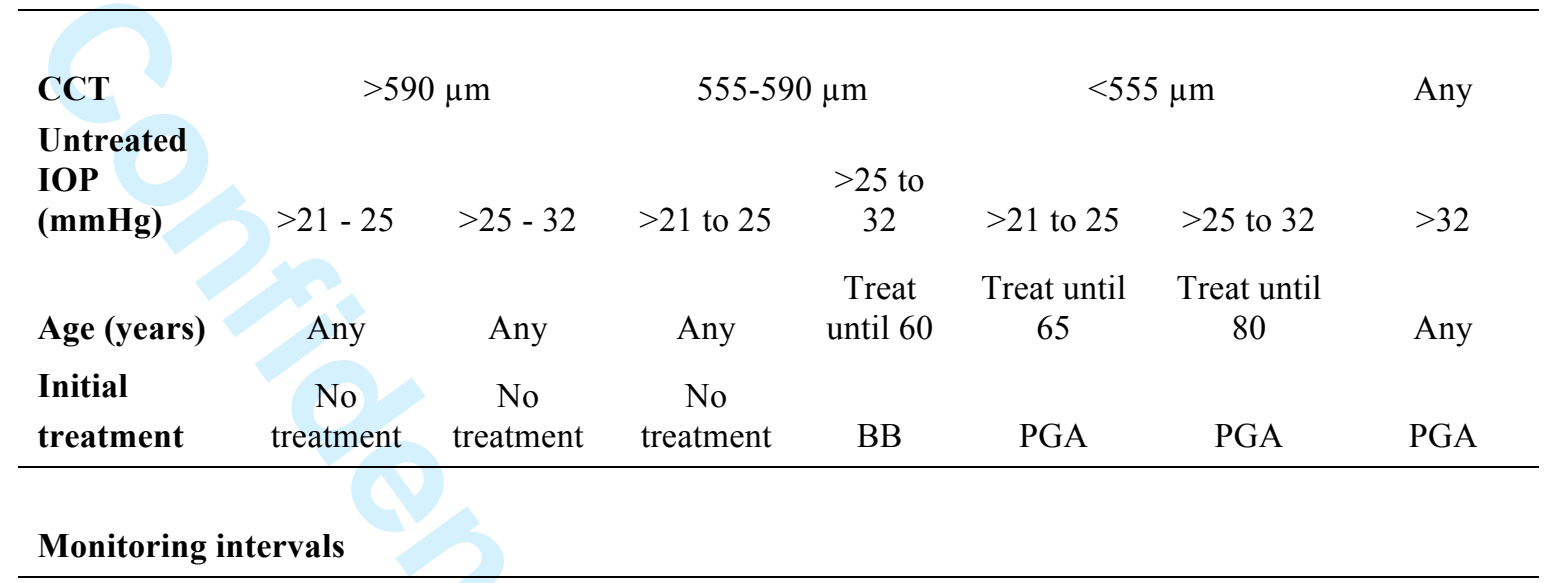

NICE intensive

\begin{tabular}{|c|c|c|c|c|c|c|c|}
\hline IOP only & $\mathrm{N} / \mathrm{A}$ & N/A & N/A & $\begin{array}{c}\text { At } 2 \\
\text { months }\end{array}$ & $\begin{array}{c}\text { At } 2 \\
\text { months }\end{array}$ & $\begin{array}{c}\text { At } 2 \\
\text { months }\end{array}$ & $\begin{array}{c}\text { At } 2 \\
\text { months }\end{array}$ \\
\hline $\begin{array}{l}\text { Full } \\
\text { assessment* }\end{array}$ & $\begin{array}{c}\text { Every } 12 \\
\text { months }\end{array}$ & $\begin{array}{l}\text { Every } 6 \\
\text { months }\end{array}$ & $\begin{array}{l}\text { Every } 6 \\
\text { months }\end{array}$ & $\begin{array}{l}\text { Every } 6 \\
\text { months }\end{array}$ & $\begin{array}{l}\text { Every } 4 \\
\text { months }\end{array}$ & $\begin{array}{l}\text { Every } 4 \\
\text { months }\end{array}$ & $\begin{array}{l}\text { Every } 4 \\
\text { months }\end{array}$ \\
\hline
\end{tabular}

NICE conservative

\begin{tabular}{|c|c|c|c|c|c|c|c|}
\hline IOP only & N/A & N/A & N/A & $\begin{array}{c}\text { At } 2 \\
\text { months }\end{array}$ & $\begin{array}{c}\text { At } 2 \\
\text { months }\end{array}$ & $\begin{array}{c}\text { At } 2 \\
\text { months }\end{array}$ & $\begin{array}{c}\text { At } 2 \\
\text { months }\end{array}$ \\
\hline $\begin{array}{l}\text { Full } \\
\text { assessment } \\
* *\end{array}$ & $\begin{array}{c}\text { Every } 24 \\
\text { months }\end{array}$ & $\begin{array}{c}\text { Every } 12 \\
\text { months }\end{array}$ & $\begin{array}{c}\text { Every } 12 \\
\text { months }\end{array}$ & $\begin{array}{c}\text { Every } \\
12 \\
\text { months }\end{array}$ & $\begin{array}{l}\text { Every } 6 \\
\text { months }\end{array}$ & $\begin{array}{l}\text { Every } 6 \\
\text { months }\end{array}$ & $\begin{array}{l}\text { Every } 6 \\
\text { months }\end{array}$ \\
\hline
\end{tabular}

$N A$, not applicable; $B B$, beta-blockers; $P G A$, prostaglandin analogue. IOP, Intraocular pressure;

CCT, Central Corneal Thickness

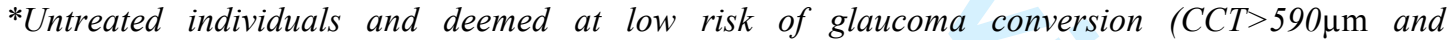
$I O P<32 \mathrm{mmHg}$ ) are not discharged and this is a deviation from the NICE guideline.

** Full assessment: IOP and assessment of the optic nerve head, and visual fields. 
Appendix 2 One-way sensitivity analyses results (discounted)

\begin{tabular}{|c|c|c|c|c|c|}
\hline *Scenario & Change & Strategy & Cost & QALY & Incremental cost per QALY (£) \\
\hline \multirow{10}{*}{$\begin{array}{c}\text { Risk threshold for initiating } \\
\text { treatment }\end{array}$} & \multirow[t]{5}{*}{$10 \%$} & Treat All & 3412 & 9.7757 & \\
\hline & & Biennial (secondary care) & 3631 & 9.7812 & 39,701 \\
\hline & & Biennial (primary care) & 4379 & 9.7807 & dominated \\
\hline & & NICE informed, conservative & 5156 & 9.7813 & $15,022,678$ \\
\hline & & NICE informed, intensive & 6879 & 9.7828 & $1,175,663$ \\
\hline & \multirow{5}{*}{$15 \%$} & Biennial (secondary care) & 3311 & 9.7805 & \\
\hline & & Treat All & 3412 & 9.7757 & dominated \\
\hline & & Biennial (primary care) & 4118 & 9.7802 & dominated \\
\hline & & NICE informed, conservative & 5156 & 9.7813 & $2,213,752$ \\
\hline & & NICE informed, intensive & 6879 & 9.7828 & $1,175,663$ \\
\hline \multirow{5}{*}{$\begin{array}{l}50 \% \text { reduction in hospital } \\
\text { costs of glaucoma } \\
\text { assessment visit }\end{array}$} & \multirow{5}{*}{$\begin{array}{c}\text { Full assessment visits (with } \\
\text { perimetry) }=£ 73 \text {; IOP only }= \\
£ 51\end{array}$} & Treat All & 2736 & 9.7757 & \\
\hline & & Biennial (secondary care) & 2814 & 9.7828 & 10,857 \\
\hline & & NICE informed, conservative & 3120 & 9.7813 & dominated \\
\hline & & Biennial (primary care) & 3180 & 9.7826 & dominated \\
\hline & & NICE informed, intensive & 3861 & 9.7828 & dominated \\
\hline \multirow{10}{*}{$\begin{array}{c}\text { Variation in cost of visits to } \\
\text { measure IOP }\end{array}$} & \multirow[b]{5}{*}{$£ 51$} & Treat All & 3188 & 9.7757 & \\
\hline & & Biennial (secondary care) & 3270 & 9.7828 & 11,410 \\
\hline & & Biennial (primary care) & $+x$ & 9.7826 & dominated \\
\hline & & NICE informed, conservative & 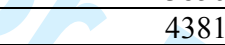 & 9.7813 & dominated \\
\hline & & NICE informed, intensive & 6075 & 9.7828 & dominated \\
\hline & \multirow[b]{5}{*}{$£ 65$} & Treat All & 3269 & 9.7757 & \\
\hline & & Biennial (secondary care) & 3523 & 9.7828 & 35,641 \\
\hline & & Biennial (primary care) & 4107 & 9.7826 & dominated \\
\hline & & NICE informed, conservative & 4659 & 9.7813 & dominated \\
\hline & & NICE informed, intensive & 6364 & 9.7828 & dominated \\
\hline \multirow{10}{*}{$\begin{array}{r}\text { Adherence for non- } \\
\text { monitoring } \\
\text { pathway } \\
\text { ('Treat All') }\end{array}$} & \multirow[b]{5}{*}{$50 \%$} & Treat All & 3412 & 9.7757 & \\
\hline & & Biennial (secondary care) & 3974 & 9.7828 & 78,911 \\
\hline & & Biennial (primary care) & 4555 & 9.7826 & dominated \\
\hline & & NICE informed, conservative & 5156 & 9.7813 & dominated \\
\hline & & NICE informed, intensive & 6879 & 9.7828 & dominated \\
\hline & \multirow[b]{5}{*}{$30 \%$} & Treat All & 3635 & 9.7699 & \\
\hline & & Biennial (secondary care) & 3974 & 9.7828 & 26,334 \\
\hline & & Biennial (primary care) & 4555 & 9.7826 & dominated \\
\hline & & NICE informed, conservative & 5156 & 9.7813 & dominated \\
\hline & & NICE informed, intensive & 6879 & 9.7828 & dominated \\
\hline \multirow{3}{*}{$\begin{array}{c}\text { Adherence for monitoring } \\
\text { pathways }\end{array}$} & \multirow[b]{3}{*}{$75 \%$} & Treat All & 3412 & 9.7757 & \\
\hline & & Biennial (secondary care) & 3974 & 9.7828 & 78,911 \\
\hline & & Biennial (primary care) & 4555 & 9.7826 & dominated \\
\hline
\end{tabular}




\begin{tabular}{|c|c|c|c|c|c|}
\hline \multirow{7}{*}{ 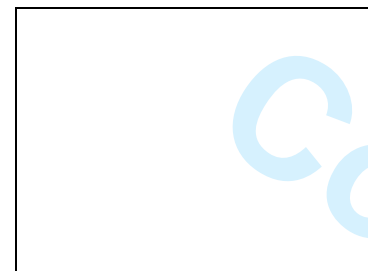 } & \multirow{7}{*}{\begin{tabular}{|l|l} 
& \\
& $90 \%$ \\
\end{tabular}} & \multirow{2}{*}{$\begin{array}{c}\text { NICE informed, conservative } \\
\text { NICE informed, intensive }\end{array}$} & \multirow{2}{*}{$\begin{array}{l}5156 \\
6879\end{array}$} & \multirow{2}{*}{$\begin{array}{l}9.7813 \\
9.7828\end{array}$} & \multirow{2}{*}{$\begin{array}{c}\text { dominated } \\
\text { dominated }\end{array}$} \\
\hline & & & & & \\
\hline & & Treat All & 3412 & 9.7763 & \\
\hline & & Biennial (secondary care) & 3715 & 9.7868 & 28,723 \\
\hline & & Biennial (primary care) & 4506 & 9.7865 & dominated \\
\hline & & NICE informed, conservative & 4864 & 9.7863 & dominated \\
\hline & & NICE informed, intensive & 6646 & 9.7879 & $2,678,852$ \\
\hline
\end{tabular}

* Results for all thresholds are reported in the health technology assessment monograph, surveillance for ocular hypertension: an evidence synthesis and economic evaluation. [8] 